$\begin{array}{ll}\text { theme } 3 & \text { strand } 2 \\ \text { identity } & \text { localities / globalities }\end{array}$

author(s) Cátia Rijo catia.rijo@gmail.com

FAUL

Helena Souto hsouto@iade.pt

IADE

\title{
Local identity trhought global design
}

The purpose of this communication is to present a reflection on the importance of culture and heritage as transmitter of cultural identity, as the measure of an identity and image representing a community, and the contributions of design as a project that ensures the development of a construction of community identity. It discusses the importance of heritage and Culture as a differential factor for the construction of a local identity, since cultural diversity takes many forms through time and space. Culture constitutes the common heritage of humanity and should be recognized and affirmed for the benefit of present and future generations. Culture as transmitter of messages must be taken and understood as an essential element in the representation of a place. This article therefore intends to discuss the importance of local culture and to see how it can survive and project globally without losing its identity, and how design can project globally.

keywords design, identity, culture, localities, globalities

\section{Introduction}

UNESCO convection aims to raise awareness at the local, national and international levels, of the importance of intangible cultural heritage ${ }^{1}$ and its mutual recognition - being the main creator of cultural diversity - as well as international cooperation and assistance in the context of an increasingly globalized world that threatens to standardize cultures of the world, while increasing social inequalities (UNESCO, 2002).

Currently, cities are constantly changing and cultural references have been lost, yielding a loss of identity and relationship to places. It is our duty, as citizens, to know and preserve our cultural heritage as portraying our history and tradition, which at the same time increases our feeling of belonging.

Maybe this is why we are currently seeing a series of initiatives aimed at the preservation of heritage, as a response to the phenomenon of cultural globalization. When to remodel? When requalifying heritage we are strengthening the significance of cultural manifestations while reinforcing our cultural identity, since as individuals we play an important role in the production, safeguarding, maintenance and recreation of the intangible cultural heritage, thereby contributing to the enrichment of cultural diversity

${ }^{1}$ The Convention considered intangible cultural heritage the practices, representations, expressions, knowledge and skills - as well as the instruments, objects, artefacts and cultural spaces associated therewith - that communities, groups and, where applicable, individuals recognize as part of their cultural heritage. 
theme 3

identity

strand 2

localities / globalities

and human creativity (UNESCO, 2002).

The designer has a role in this enrichment of cultural diversity, as an active agent in the same creation; the choices it makes and the messages it conveys are components of a public cultural reality.

\section{The designer as transmitter of cultural identity}

In a broad sense design is understood as a methodology which is used to achieve a certain goal and /or outcome. Julier Guy said that visual culture plays a key role in the formation of cultural representation. According to the author, visual culture is an expression of great intrinsic cultural and social significance. Culture is more than a pure representation or narrative, where the culture transmits visual messages, and instead culture formulates, formats, circulates, and retrieves information (Julier, 2008:29)

As previously mentioned, the designer is an active agent in cultural construction as well as providing the "culture's" shape whilst also creating culture, created by the work itself. The way that the receptors react and interpret themselves creates another culture: a culture of consumption, which is based on the culture of image and value of object. So the designer's mission is to assign value to our cultural heritage - tangible or intangible -and guarantee that the cultural heritage is not overwhelmed by global elements.

The designer plays a decisive role in communication, symbolic relationships, as well as the relationship of the individual with the society in which they operate. Above all, the designer should try to assess the differentiating features of the object that's being communicated to ensure that the product itself has an emotional relationship with the receiver.

In this sense, the designer should not forget its main function: to create visual information that relates to the object to communicate.

Therefore, the designer fulfils its function, as Victor Margolin wrote:

"The designer should seek to investigate new ideas and try to understand how design affects human action. (...) Design culture relates to the subjects that study human behaviour (such as sociology and anthropology) and at the same time is linked with subjects that study objects (such as art history and material culture." (Margolin, 2008:28)

In the end, the designer has responsibility in their work, trying to translate and transmit culture and our cultural diversity to be perceived and understood by the society in which it operates.

\section{Culture and identity: from local to global}

The designer, in order to properly construct visual symbols that represent the tangible and intangible culture of the society in which it operates and communicate them globally, must identify that identity, culture, heritage or traditions (among others) that define the community. For this it is essential to understand what these concepts cover.

Culture is the human construction and interpretation of symbols and meanings that are shared, which identifies a particular community, differentiating itself from others through their cultural identity. 
In the anthropological sense, Culture is defined as "a set of material and immaterial culture that identifies a particular community"2 and can be interpreted through different aspects: through behavioural characteristics that are unique to humans, by analysing that human beings have to generate behaviours, and through the ability of the human mind to create endless flexible reactions, through its symbolic and linguistic potential (Santos, 2005). According to this anthropological definition, we can distinguish two forms of culture: material and immaterial.

Material culture is any product that results from human production, it is the set of artefacts that combine raw materials and technology, distinguishing itself from fixed structures by its mobility. Already immaterial culture means the knowledge that was not transmitted through books or any other records or forms, but the one that is passed down through the generations in practice. For these reasons, tradition and knowledge are therefore essential factors for the continuity of intangible culture and the construction of the identity of a community or people.

According to Stuart Hall (1998:77), currently national cultures are a union of the main sources of cultural identity and "constituted not only of cultural institutions, but also by symbols and representations that produce the feeling of belonging to the local feelings with which we identify, thereby constructing identities."

The national culture is constituted not only of cultural institutions, but also by symbols and representations that produce the feeling of belonging to the local feelings with which we identify, thereby constructing identities.

These feelings contain stories that are told about the place, memories that relate the present with the past from which images are constructed. In addressing this issue the author argues that one of the consequences of globalization is the strengthening or creation of new national and local identities, in other words, globalization produces a new interaction between the global and the local (Hall, 1998).

Local diversity plays an important role in this process of globalization because it discloses the local culture on a global level, communicating to and distinguishing for others its unique characteristics, leading to a collective recognition of the same. So, it could be said, that society is an identity isolated from other existing ones.

In a broad sense, identity is the "set of characteristics (physical and psychological), essential and distinctive to someone, a social group or something else." 3

Both culture and cultural identity of a society is the result of crossing heritage with history and evolution over time, where belongs to a particular local identity means knowing ourselves as different to others.

${ }^{2}$ The Convention considered intangible cultural heritage the practices, representations, expressions, knowledge and skills - as well as the instruments, objects, artefacts and cultural spaces associated therewith - that communities, groups and, where applicable, individuals recognize as part of their cultural heritage. The term culture emerged in 1871 as a summary of the terms and Kultur Civilization, the French term referring to the material achievements of a people, the German term that symbolized the spiritual aspects of a community and in that year, Edward Taylor synthesized in the English word Culture. Thus, in one word Tylor covers all human and increasingly at the idea of culture as an innate disposition, perpetuated biologically (The Columbia Encyclopaedia, 2008).

${ }^{3}$ Infopédia [Online]. Port: Porto Editora, 2003-2013. [Consult. 2013-10-01]. 
theme 3

identity

strand 2

localities / globalities

Currently we are rediscovering this place as opposed to global, cultural events, traditions which interprets equity as an asset that represents identity and sets the value of a culture. According to UNESCO:

"Cultural Heritage designates a monument, group of buildings or site of historical, aesthetic, archaeological, scientific, ethnological and anthropological value." (UNESCO, 2002)

At a time that we are rediscovering the value of heritage, as an element of cultural identity, it becomes crucial to its dissemination and projection. In that way, the preservation of material culture leads to a global identification while contributing to the formation of the sense of belonging to the community.

The designer should have the ability to convey the feeling of belonging and highlight this asset, communicating it to outside.

\section{Local or global: who we are?}

At a time when society is characterized by this inter-connection to all points of the world (through communication, transport our others), it makes more sense than ever, to raise the issue of place and globalization.

Globalization implies an understanding of the distance between the classic sociological concept of "society" as delimited by a perspective that focuses on how social life is ordered across time and space (Giddens, 2001:64). Often this globalized system evokes in citizens the sensation of not belonging to any specific place and belonging to all. However, there are differences that distinguish the different existing communities in the world, often the communication between the local and global does not always work as desired.

"(...) It is fair to say that local culture and the local " place" is more important than the global for most people. (...) But it is important to remember that globalization and localization are linked, and sometimes when speaking of globalization, there remains much uncertainty and discussion around the question of how these two concepts are linked." (Servaes, 2001:2)

The truth is, that it is in a geographically well-defined place that individuals develop their life and develop their habits; these are places where people cultivate their customs and create social relationships.

Both culture and cultural identity of a community resulting from the crossing of its heritage with history and evolution over time, which belongs to a particular local identity, means knowing ourselves and being different from the global.

The author defines place - while anthropological space -as a space of identity, relative and historical, that creates and fosters interpersonal relationships, moving in a very well defined time and space. The space is two things at the same time: principally the sensation for those who live there and principally of the intelligibility for the beholder (Augé, 2005).

For that reason, anthropological spaces are spaces where there is the materialization of social identity and have three characteristics in common: identity, relativity and history. 
The exposure of places is the symbolization of space originating through living and human relationships. It is called the anthropological place because the space develops a community identity relationship, as well as its common history, thereby developing certain codes, signs and symbols themselves. The author goes further and makes the distinction between objective place and symbolic place: the first is characterized by the application of objective marks of identity and history in the space (for example: churches, public places, schools etc.), the second is characterized by the way the spaces are defined and the relationship that others create with the space itself (for example: residence and language) (Augé, 2005:27).

The designer should use these features in symbolic representation of local identity, because they are the reference that allows external and internally recognition.

"The human symbolization (...) allows it to become readable to all those who attend the same space, a number of organised schemes, ideological and intellectual brands, ordering the social. These three main themes are identity, relationship, and precisely history." (Augé, 2005:51)

In the end you could say that we all are local at the same time we are global, and it is up to the designer be able to download this multiplicity of identity in visual and symbolic representations that make the space.

\section{Conclusion}

According to the UNESCO Universal Declaration on Cultural Diversity (2002): cultural diversity contributes to the existence of intellectual, emotional, moral and spiritual satisfaction and constitutes one of the essential elements for the transformation of urban and social reality. Culture takes diverse forms across time and space, constituting the common heritage of humanity and should be recognized and affirmed for the benefit of present and future generations.

Architecture, art, history, landscape, climate, local culture is what defines your story. Each city or place must communicate and project its characteristics using a strong identity, which is easy to understand in order to create an emotional relationship with the community. Its identity must relate to the most representative features of the site.

Through images and symbols the designer should try to portray the differentiating features of the site while at the same time referring to cultural heritage that represents the contemporary existing therein. This representation should be made without loss of local identity while it is associated with globalization.

To achieve this goal the designer must assess the differentiating features in order to achieve a representation of a place's identity and also develop an emotional relationship with the receiver. In other words, the designer should create a visual image based on distinguishing attributes of the place in order to strengthen its identity.

\section{References}

Augé, M. (2005) Não-lugares: introdução a uma antropologia da supermodernidade. Campinas: Papirus. 
Castells, M. (1999) A era da informação: economia, sociedade e cultura. Vol. I. A Sociedade em Rede. São Paulo, Paz e Terra.

Chaves, N. (2001) El oficio de diseñar - Propuestas a la conciencia crítica de los que comienzan. Barcelona: Editorial.

Giddens, H. (2001) O Mundo na Erra da Globalização. $3^{a}$ edição. Lisboa: Editorial Presença. Hall, S. (1998) A identidade cultural na pós-modernidade. Rio de Janeiro: DP\&A.

Hornskov, B. (2007) On the management of authenticity: Culture in the place branding of Oresund. Place Branding and Public Diplomacy, Vol. 3.

Julier, G. (2008) The culture of design. Publication: London : Sage, 2008.

Lynch, K. (1960) The Image of the city. Lisboa, edições 70.

Margolin, V.(2002) The politics of the artificial; essays on design and design studies.

Chicago: University of Chicago Press, 2002.

Munari, B. (1998) A arte como ofício. Lisboa: Editorial Presença.

Peralta, E. (2000) Património e identidade. Os desafios do turismo cultural. in http://ceaa. ufp.pt/turismo3.html

Raposo, D. (2003) Design Gráfico - Comunidade Brasileira de Design.

in http://www.designgrafico.art.br/comapalavra/designparatodos.htm

Ribeiro, A. (2004) Abrigos - Condições das Cidades e Energias da Cultura. Editor Cotovia. Santos, R. (2005) Antropologia para quem não vai ser antropólogo. Porto Alegre: Tomo Editorial. Servaes, J. (2001) Los medios de comunicacion: globalizacion atraves de la localizacion. PCLA, Espanha.

UNCTAD (2010) Creative Economy Report. United Nations, Geneva. Unesco- Declaração Universal sobre a Diversidade Cultural, 2002. 